\title{
Biotic and Abiotic Factors Interact to Regulate Northern Peatland Carbon Cycling
}

\author{
Alona Armstrong, ${ }^{1,3 *}$ Susan Waldron, ${ }^{1}$ Nicholas J. Ostle, ${ }^{2,3}$ \\ Harriett Richardson, ${ }^{1,2}$ and Jeanette Whitaker ${ }^{2}$
}

\begin{abstract}
${ }^{1}$ School of Geographical and Earth Sciences, University of Glasgow, Glasgow, UK; ${ }^{2}$ Centre for Ecology \& Hydrology, Lancaster Environment Centre, Lancaster University, Lancaster, UK; ${ }^{3}$ Present address: Lancaster Environment Centre and Energy Lancaster, Lancaster University, Lancaster, UK
\end{abstract}

\begin{abstract}
Understanding the spatio-temporal variability of controls on peatland carbon (C) cycling is essential to project the effects of future environmental change. While there is understanding of individual drivers of $\mathrm{C}$ cycling, the effect of multiple drivers, including interactions, remains poorly understood. Using a spatially and temporally explicit sampling framework, we examined the effects of biotic and abiotic controls on key indicators of peatland functioning: ecosystem respiration $\left(R_{\text {eco }}\right)$, photosynthesis $\left(P_{\text {cal }}\right)$, net ecosystem exchange (NEE), methane $\left(\mathrm{CH}_{4}\right)$ fluxes, and pore water dissolved organic carbon concentration ([DOC]). Measurements were made over 12 months in a blanket peatland hosting a wind farm in Scotland, UK. Overall, we found that (i) season and plant functional type (PFT) explained most variation in $R_{\text {eco }}$ and $P_{\text {cal }}$ (ii) PFT and spatial location within the wind farm, which integrates several peat proper-
\end{abstract}

ties, were dominant predictors of $\mathrm{CH}_{4}$ fluxes, and (iii) season and location within the wind farm correlated with pore water [DOC]. Examination of predictors indicated that interactions, between and within biotic and abiotic factors, explained a significant amount of variation in greenhouse gas fluxes and [DOC]. These findings indicate that combinations of biotic and abiotic factors could mediate or exacerbate the effects of future environmental change on peatland C cycling. Given this, studies of $\mathrm{C}$ cycling need to capture the spatial and temporal variance of biotic and abiotic factors and their interactions to project the likely impacts of environmental change.

Key words: spatial variation; temporal variation; interactions; peatland; greenhouse gas flux; dissolved organic carbon.

\section{INTRODUCTION}

Peat soils are globally important carbon (C) stores, with approximately one-quarter of the world soil C

Received 9 February 2015; accepted 11 June 2015; published online 30 September 2015

Author contributions AA, NO, SW, andJW designed the study; AA, NO, HR, SW performed the research. AA analyzed the data. AA led the writing of the paper with inputs from NO, HR, SW, and JW.

*Corresponding author; e-mail: a.armstrong@lancaster.ac.uk stock, 547 Gt C, stored in northern peatlands (Jobbágy and Jackson 2000; Yu and others 2010). The $\mathrm{C}$ balance of a peatland is dependent on fluxes of $\mathrm{C}$ to and from the system, primarily the influx and efflux of greenhouse gases (GHG), carbon dioxide $\left(\mathrm{CO}_{2}\right)$, and methane $\left(\mathrm{CH}_{4}\right)$, and the production and export of dissolved organic and inorganic carbon (DOC, DIC) (Kutsch and others 2009). These fluxes reflect biological processes by which $\mathrm{C}$ is assimilated and processed. $\mathrm{CO}_{2}$ is released 
through decomposition of organic matter, plant respiration, and the oxidation of $\mathrm{CH}_{4}$ (positive fluxes, together hereafter termed ecosystem respiration) and taken up through photosynthesis (negative fluxes). The balance of ecosystem respiration and photosynthesis is net ecosystem exchange and indicates if $\mathrm{C}$ is being sequestered (negative flux) or released (positive flux). $\mathrm{CH}_{4}$ is produced during anaerobic decomposition but can be oxidized into $\mathrm{CO}_{2}$ by methanotrophs. Methanotrophs can also oxidize atmospheric $\mathrm{CH}_{4}$, leading to negative fluxes. DOC can be produced under aerobic and anaerobic conditions and exported from peatlands by drainage channels, but also acts as a substrate for microbes, with $\mathrm{CO}_{2}$ efflux from streams comprising an important component of the overall C balance (Billett and Harvey 2013). Measurements of GHG fluxes represent the contributions of the sampling plots, whereas [DOC] values are a result of production (including mobilization into the dissolved phase), microbial degradation, input of water from precipitation at the sampling point, and inflow and outflow of water and DOC from upslope and downslope. Consequently the pore water [DOC] values give an indication of both potential DOC runoff [although discharge is known to dominate fluxes (Armstrong and others 2010)], and substrate available for microbial decomposition which may feed back to GHG fluxes.

Characteristics of the biotic communities, both plant and soil, influence the assimilation and processing of $\mathrm{C}$ in peatlands. The composition and structure of the vegetation regulates $\mathrm{C}$ cycling as different plant functional types (PFTs) have specific traits that dictate how they cycle C (Díaz and others 2007; De Deyn and others 2008; Ward and others 2009; Armstrong and others 2012). Traits can be ecophysiological (for example, their nitrogen $(\mathrm{N})$ use efficiency), biochemical (for example, how they influence litter nutrient content), demographical (for example, diameter of growth), morphological (for example, root architecture), or phenological (for example, flowering time) (Lavorel and others 2007). Many plant functional traits are associated with growth rate, with fast-growing plants typically characterized by a greater photosynthetic capacity, shorter lifespan, lower dry matter content, and greater and higher quality litter inputs than slower growing species (Aerts and Chapin III 1999). Peatlands are dominated by shrubs, sedges, and mosses, with sedges relatively fast growing and shrubs relatively slow growing. Soil faunal and microbial communities are also central to peatland C cycling, stimulating decomposition and nutrient supply, with consequent effects on productivity and plant community composition (Bardgett and others 2008; Weedon and others 2012; Bragazza and others 2014).

Biological C cycling processes respond to abiotic conditions, with climate established as a dominant control (Freeman and others 2001; Dorrepaal and others 2009). As a consequence, much research has considered the response of both GHG and pore water [DOC] to temperature and water table (including their interactions) (Bubier and others 2003; Holden 2005; Ise and others 2008; Clark and others 2009). In northern latitudes, there are strong seasonal controls over GHG exchange and [DOC]: warmer temperatures generally enhance $\mathrm{C}$ cycling in summer (Ward and others 2007; Clark and others 2008) while seasonally lower water tables decrease photosynthesis rates and net $\mathrm{CH}_{4}$ emissions, and increase respiration and DOC production (Blodau and others 2004). However, increases in DOC production may not be apparent in pore and stream water DOC samples until autumn when the water table commonly rises causing an 'autumn flush' of DOC produced over the summer (Grayson and Holden 2012).

Other abiotic properties also influence the biological processing of $\mathrm{C}$ in peatlands. Physical properties, such as peat depth and bulk density, affect $\mathrm{C}$ cycling through controlling substrate availability and the diffusion rates of water, compounds, and gas through the peat profile (Dorrepaal and others 2009; Levy and others 2012). The chemical composition of the peat, including nutrient availability and the level of secondary metabolites, also exerts a significant influence on both productivity and decomposition (Bragazza and others 2006). For example, 7 years of $\mathrm{N}$ addition decreased $\mathrm{C}: \mathrm{N}$, increased bacterial biomass, and stimulated soil enzyme activities in an Italian alpine peatland (Bragazza and others 2012).

There are known interactions between and within biotic and abiotic controls, for example, the thermal conditions of peat are affected by the water table depth (Kettridge and Baird 2008). Further, litter quality, a plant functional trait and thus a biotic property, influences the chemical composition of the peat (Bragazza and others 2013), an abiotic property. Moreover, physical and chemical peat properties may influence plant and microbial community composition and thus indirectly affect peatland C cycling (De Deyn and others 2008). However, these interactions are poorly resolved as initial studies examining the effect of environmental change on peatland $\mathrm{C}$ cycling focused on single drivers (Freeman and others 1992). More recently the result of multiple drivers changing 
simultaneously has been elucidated by examining more than one driver and the interactions between them (Ellis and others 2009), but knowledge of interactions between abiotic and biotic factors remains poorly understood (Ward and others 2013). Moreover, many studies imposed treatments and thus results may be indicative of the short-term transition state rather than longer term effects (Bubier and others 2007).

Interactive effects, both between and within biotic and abiotic properties, maybe synergistic or antagonistic. For example, plant community composition can modulate the effects of temperature warming, necessitating projections of future peatland $\mathrm{C}$ sink strength to take into account any concurrent changes in vegetation (Ward and others 2013). Further, nutrient addition can cause a reduction in photosynthesis despite an increase in shrub biomass and leaf area, as a result of reduced moss cover and increased shading by shrubs and litter accumulation (Bubier and others 2007). Therefore, there is a critical need to examine the role of biotic and abiotic factors and their interactions play in the functioning of natural peatland ecosystems. The understanding generated will provide valuable insight into the potential implications of future environmental change. Further, it will provide a firmer basis for inference of the effect of environmental change on peatlands with different biotic and abiotic characteristics, and the implications of natural or managed vegetation change.

The overarching aim of this study was to determine the role of abiotic and biotic factors as regulators of peatland GHG fluxes and pore water [DOC]. To achieve this, we established a factorial field experiment and subsequently measured GHG fluxes (that is, $R_{\text {eco, }}, P_{\text {cal }}, \mathrm{NEE}$, and $\mathrm{CH}_{4}$ ) and pore water [DOC] for 12 months to assess how ecosystem C cycling processes varied temporally and spatially. First, we examined the effects of season, PFT, and site, which integrates abiotic and biotic factors that vary spatially across the peatland. Second, biotic and abiotic metrics were used to explain variances in carbon cycling, including peat temperature, water table depth, PFT biomass (that is, shrubs, sedges and mosses), peat depth, bulk density, and peat $\mathrm{C}$ and $\mathrm{N}$ contents. We hypothesized that (1) PFT explains more of the variation in ecosystem $\mathrm{CO}_{2}$ and $\mathrm{CH}_{4}$ fluxes and [DOC] than spatial variation 'site'; and (2) interactions, both between and within biotic and abiotic factors, explain a significant proportion of the variance in GHG fluxes and [DOC] in northern peatlands.

\section{Methods}

\section{Study Site}

This study was undertaken at Black Law Wind Farm, Scotland $\left(55^{\circ} 46^{\prime} 01^{\prime \prime} \mathrm{N} 03^{\circ} 44^{\prime} 20^{\prime \prime} \mathrm{W}\right.$, altitude $250-320 \mathrm{~m})$. The wind farm covers $18.6 \mathrm{~km}^{2}$ of blanket bog, grassland, and plantation forestry. The blanket bog is typical of UK peatlands in terms of microtopography and vegetation [National Vegetation Community M19 Calluna vulgaris - Eriophorum vaginatum blanket mire (Rodwell 2000)]. Four sites, coded from A to D, along a $3.5 \mathrm{~km} \mathrm{SW}$ to NE transect, were established in areas of blanket bog. The sites were selected to be broadly visually similar, but given the inherent spatial variability of the blanket bog, sites A and B had thinner peat, and were less hummocky and shrubby compared with sites $\mathrm{C}$ and D. Within all four sites, the dominant PFT of mosses, sedges and shrubs were found, with the most prevalent species being Sphagnum spp. (hollow), Calluna vulgaris (hummock), and Eriophorum angustifolium (hummock). Within each site, four blocks were established, each dominated by one of the three PFTs ( $n=12$ at each site; $n=48$ in total). A wooden sampling platform was installed at the plots to minimize disturbance during site visits. At each sampling plot, NEE, $R_{\text {eco, }} \mathrm{CH}_{4}$ flux, pore water [DOC], and water table depth were measured monthly for 1 year commencing from May 2011; peat temperature was recorded every $30 \mathrm{~min}$ at three of the four blocks and vegetation biomass and peat properties were characterized once. The vegetation cover at Black Law was very patchy, thus there was a minimum buffer area (that is, the same PFT) of $5 \mathrm{~cm}$ around the monitoring equipment (plots were at least $40 \mathrm{~cm}$ by $40 \mathrm{~cm}$ ).

Vegetation Biomass Above-ground biomass within the GHG sampling plots was estimated in August (time of peak biomass) 2011 by selecting a similar plot nearby (to avoid destructive harvesting of the GHG sampling plots), harvesting all of the vegetation (including other PFTs present), oven drying it at $50^{\circ} \mathrm{C}$, and weighing the dry mass of each PFT.

Peat Properties Peat temperature was recorded at $5 \mathrm{~cm}$ depth using Onset Hobo Pendant temperature loggers (Onset, USA). C and $\mathrm{N}$ contents of peat surrounding each block were evaluated from a $0.1 \mathrm{~g}$ homogenized and oven-dried $\left(65^{\circ} \mathrm{C}\right)$ subsample of a $15 \mathrm{~cm}$ long, $5 \mathrm{~cm}$ diameter peat core using a LECO Truspec CN Analyzer (LECO, USA) and C:N was calculated (Carter and Gregorich 2007). Dry bulk density was calculated from a core of the same size, with the peat dried at $105^{\circ} \mathrm{C}$ (Carter and Gregorich 2007). There may be varia- 
tion in temperature, $\mathrm{C}, \mathrm{N}$, and bulk density with depth. Average peat depth for each plot was calculated from triplicate probed peat depths within $100 \mathrm{~cm}$ of each plot.

Greenhouse Gas Fluxes $\mathrm{CO}_{2}$ and $\mathrm{CH}_{4}$ (hereafter abbreviated to GHG) fluxes were measured using static chambers, as detailed in Ward and others (2007), at each of the 48 plots. Six weeks prior to the first measurement, $30 \mathrm{~cm}$ diameter plastic collars were carefully inserted to the litter-peat interface, minimizing root damage. If there was not an airtight seal, peat from the surrounding area was used to create a seal on the outside of the collar. $R_{\text {eco }}$ and NEE were measured using an EGM-4 portable infrared gas analyzer (PP Systems, USA) and $\mathrm{CH}_{4}$ by taking samples for analysis in the laboratory using a Perkin Elmer Autosystem XL Gas Chromatograph, as detailed in Ward and others (2013). $R_{\text {eco }}$ and $\mathrm{CH}_{4}$ were measured using dark chambers and NEE using a transparent chamber. The measurements were quality controlled and those affected by poor chamber seals, leaking vials or instrument malfunction removed. Fluxes, as mg $\mathrm{CO}_{2}-\mathrm{C}$ or $\mathrm{CH}_{4}-$ $\mathrm{C} \mathrm{m} \mathrm{m}^{-2} \mathrm{~h}^{-1}$, were calculated following Levy and others (2012).

Photosynthesis $\left(P_{\text {cal }}\right)$ was calculated by subtracting $R_{\text {eco }}$ from NEE: positive NEE indicates land-toatmosphere exchange dominates and negative indicates atmosphere-to-land, that is, the peat is a source and sink, respectively. Extreme $\mathrm{CH}_{4}$ fluxes, ascribed to measurement error (Christiansen and others 2011) or ebullition events (Baird and others 2004), were excluded using thresholds of -1.15 to $11.55 \mathrm{mg} \mathrm{m}^{2} \mathrm{~h}^{-1} \mathrm{CH}_{4}$ as prescribed by Levy and others (2012). Consequently, our results are only applicable to non-ebullition $\mathrm{CH}_{4}$ fluxes.

Hydrology Water table depth was measured within 30 min of GHG measurements using a dip well $(2.2 \mathrm{~cm}$ diameter plastic tubing with perforations along its length below ground). Water table values above $0 \mathrm{~cm}$ represent a saturated litter layer or water ponding on the surface. Pore water samples (peat surface to $15 \mathrm{~cm}$ depth) were collected from a second dip well $(2.2 \mathrm{~cm}$ diameter perforated plastic tubes with sealed bases). The pore water dip wells were emptied and the refill sampled after $24 \mathrm{~h}$. The samples were stored at $4^{\circ} \mathrm{C}$, filtered to $0.7 \mu \mathrm{m}$ within $36 \mathrm{~h}$, and analyzed for [DOC] within 2 months. The samples were analyzed for [DOC] by high temperature oxidation using a Thermalox Total $\mathrm{C}$ analyzer. Potassium phthalate was used to produce standards and the precision of sample analysis was less than $0.5 \mathrm{mg} \mathrm{l}^{-1} \mathrm{C}$.

\section{Data Analysis}

For statistical analysis, the temperature closest to the mid-point of the GHG measurement time was selected but for [DOC] the average temperature over the $24 \mathrm{~h}$ preceding collection was calculated (as the sample was an integration of water movement in the previous $24 \mathrm{~h}$ ). The sampling dates were categorized into spring (March-May), summer (June-August), autumn (September-November), and winter (December-February) (Jenkins and others 2008).

To test our hypothesis that PFT explains more of the variance in ecosystem $\mathrm{CO}_{2}$ and $\mathrm{CH}_{4}$ fluxes and [DOC] than the integrated effect of location on the peatland, repeated measures mixed effects models were used to explain the importance of season, PFT, and site, and their interactions for total biomass, peat temperature, water table depth, bulk density, peat depth, C, N, C:N, $R_{\text {eco }}, P_{\text {cal }}, \mathrm{NEE}, \mathrm{CH}_{4}$, and [DOC]. This analysis was chosen as it provides a broad scale overview of the relative importance of groups of factors that vary with season (climate), PFT, and site (peat biological, and chemical and physical properties, some of which were not measured in this study). The distributions of response variables were assessed and the data transformed to promote normality as required: $R_{\mathrm{eco}}, P_{\mathrm{cal}}, \mathrm{CH}_{4}$, and [DOC] were logarithmically transformed, and the remainder were not transformed. To enable logarithmic transformation (that is, to eradicate negative values), $P_{\text {cal }}$ was multiplied by $-1,35$ was added to each $\mathrm{CH}_{4}$ measurement, and 1000 added to each NEE measurement. The distribution of residuals and residual versus fitted data plots were constructed for each model. Individual drivers and interactions with a $P$ value $<0.05$ were deemed as significant. The effect size of the individual drivers and interactions were inferred from $\chi^{2}$ values.

To test our hypothesis that interactions, both between and within biotic and abiotic factors, explain a significant proportion of the variance in GHG fluxes and [DOC] in northern peatlands, generalized linear models (GLM) with a log-link and gamma distribution were used to assess the role of the biotic (biomass of each PFT) and abiotic (temperature, water table depth, bulk density, peat depth, C, N, and C:N) factors and their interactions in driving GHG fluxes and [DOC]. This approach was chosen to explore the importance of interactions over peatland $\mathrm{C}$ cycling. To allow interpretation of both the individual drivers and interactions, including their relative effect sizes, the explanatory variables were transformed (centered and standardized following Schielzeth (2010)): the coeffi- 
cients are indicative of effect size. As before, the $P_{\text {cal }}$ data were multiplied by $-1,35$ were added to each $\mathrm{CH}_{4}$ measurement, and 1000 added to each NEE measurement to allow the GLM models to run with a log-link. To avoid model over-specification given the large number of explanatory variables, the modeling was undertaken in three stages: (1) check for a relationship between the response variables and explanatory variables in turn and exclude nonsignificant factors from model development; (2) build a GLM model with the remaining explanatory variables and two-way interactions, ensuring that no explanatory variables were correlated (threshold of $r=0.80$ used); and (3) step-wise removal of insignificant individual drivers $(p>0.05)$ and interactions. Model fit plots were assessed and pseudo- $R^{2}$ was calculated from the observed and predicted values. To assess the importance of interactions, the coefficients (absolute values) were summed and compared. To explore the interactions, plots of the predicted GHG flux or [DOC] using the mean of the explanatory variables and one standard deviation above and below were drawn. Stata 13 was used for all data analysis (StataCorp. 2013).

\section{RESUlts}

The mixed effects models, based on season, PFT, and site, explained between 37 and $55 \%$ of the variation in [DOC] and GHG fluxes, with the exception of NEE, for which only $21 \%$ of the variation was explained (Table 1). The GLM models, based on biotic and abiotic factors and their interactions, explained between 33 and $59 \%$ of the variance in GHG fluxes and [DOC], again except for NEE for which only $10 \%$ was explained (Table 2 ).
Below we describe our results in relation to our hypotheses that (1) PFT explains more of the variation in ecosystem $\mathrm{CO}_{2}$ and $\mathrm{CH}_{4}$ fluxes and [DOC] than the integrated effect of properties that vary with location on the peatland and (2) interactions, both between and within biotic and abiotic factors, explain a significant amount of the variance in GHG fluxes and [DOC] in northern peatlands.

The Importance of Season, PFT, and the Integrated Effect of Spatially Varying Properties

The biotic and abiotic metrics varied with season, PFT, and site, with water table varying with all three and biomass with PFT and site (Table 3). As expected, given the northern latitude of Black Law, season explained the most variation in temperature and water table, with the warmest temperatures and lowest water tables observed in summer, coldest temperatures in winter, and highest water tables in autumn (Tables 3,4). Site explained significant variability in bulk density, water table, peat depth, biomass, peat $\mathrm{C}$ and $\mathrm{N}$ contents, and $\mathrm{C}: \mathrm{N}$ and, with the exception of water table, site explained more of the variance in these factors than season or PFT (Table 3). Site A had the shallowest peat, lowest peat $\mathrm{C}$ content (which was similar at the other sites), highest bulk density and C:N, and intermediate water table depths (Tables 3,4). Site $\mathrm{B}$ had the lowest bulk density and water table and intermediate C:N (Tables 3, 4). Site C had the deepest peat, the lowest water table depth and C:N, the highest $\mathrm{N}$ content, and intermediate bulk density. Finally, site D had highest biomass (which was similar at all other sites), water table and C:N

Table 1. Repeated Measures Mixed Effect Model Results Examining the Influence of Plant Functional Type (PFT), Site (SI), and Season (SE) on GHG Fluxes and [DOC]

\begin{tabular}{|c|c|c|c|c|c|c|c|c|c|c|c|}
\hline \multirow[t]{3}{*}{ Factors } & \multirow[t]{3}{*}{ Df } & \multirow{2}{*}{\multicolumn{2}{|c|}{$\begin{array}{l}R_{\text {есо }} \\
n=541 \\
R^{2}=0.52\end{array}$}} & \multirow{2}{*}{\multicolumn{2}{|c|}{$\begin{array}{l}P_{\text {cal }} \\
n=497 \\
R^{2}=0.37\end{array}$}} & \multirow{2}{*}{\multicolumn{2}{|c|}{$\begin{array}{l}\text { NEE } \\
n=570 \\
R^{2}=0.21\end{array}$}} & \multirow{2}{*}{\multicolumn{2}{|c|}{$\begin{array}{l}\mathrm{CH}_{4} \\
n=517 \\
R^{2}=0.51\end{array}$}} & \multirow{2}{*}{\multicolumn{2}{|c|}{$\begin{array}{l}\text { DOC } \\
n=454 \\
R^{2}=0.55\end{array}$}} \\
\hline & & & & & & & & & & & \\
\hline & & $\chi^{2}$ & $P>\chi^{2}$ & $\chi^{2}$ & $P>\chi^{2}$ & $\chi^{2}$ & $P>\chi^{2}$ & $\chi^{2}$ & $P>\chi^{2}$ & $\chi^{2}$ & $P>\chi^{2}$ \\
\hline PFT & 2 & 68.1 & 0.00 & 33.9 & 0.00 & 12.9 & 0.00 & 67.3 & 0.00 & 1.6 & 0.45 \\
\hline SI & 3 & 8.2 & 0.04 & 11.8 & 0.01 & 13.8 & 0.00 & 77.6 & 0.00 & 47.5 & 0.00 \\
\hline SE & 3 & 366.9 & 0.00 & 150.8 & 0.00 & 27.9 & 0.00 & 56.2 & 0.00 & 251.1 & 0.00 \\
\hline $\mathrm{PFT}^{*} \mathrm{SI}$ & 6 & 3.2 & 0.78 & 4.3 & 0.63 & 9.6 & 0.14 & 2.0 & 0.92 & 7.6 & 0.27 \\
\hline $\mathrm{PFT}^{*} \mathrm{SE}$ & 6 & 21.2 & 0.00 & 24.7 & 0.00 & 20.6 & 0.00 & 5.7 & 0.46 & 4.5 & 0.60 \\
\hline $\mathrm{SI}{ }^{*} \mathrm{SE}$ & 9 & 36.5 & 0.00 & 19.4 & 0.02 & 48.7 & 0.00 & 12.3 & 0.20 & 110.0 & 0.00 \\
\hline
\end{tabular}

The average values of each GHG and [DOC] are given in Table 5.

$n=$ number of data points; $R^{2}=$ pseudo $R^{2}$ calculated from the square of the correlation between the observed and actual values; $D f=$ degrees of freedom; $\chi^{2}=$ chi ${ }^{2}$ value; $P=P$ value. 
Table 2. The Coefficients (Coef), Standard Errors (SE), and $P$ Values $(P>z)$ for All Significant Terms in the GLM Models

\begin{tabular}{|c|c|c|c|c|c|c|c|c|c|c|c|c|c|c|c|}
\hline \multirow[b]{2}{*}{ Variables } & \multicolumn{3}{|c|}{$R_{\mathrm{eco}}, R^{2}=0.47$} & \multicolumn{3}{|c|}{$P_{\mathrm{cal}}, R^{2}=0.50$} & \multicolumn{3}{|c|}{$\mathrm{NEE}, R^{2}=0.10$} & \multicolumn{3}{|c|}{$\mathrm{CH}_{4}, R^{2}=0.59$} & \multicolumn{3}{|c|}{$[\mathrm{DOC}], R^{2}=0.33$} \\
\hline & Coef & SE & $P>z$ & Coef & SE & $P>z$ & Coef & SE & $P>z$ & Coef & SE & $P>z$ & Coef & SE & $P>z$ \\
\hline $\mathrm{T}$ & 0.52 & 0.03 & 0.00 & 0.53 & 0.04 & 0.00 & & & & & & & 0.32 & 0.03 & 0.00 \\
\hline WT & -0.13 & 0.03 & 0.00 & 0.11 & 0.04 & 0.01 & & & & & & & & & \\
\hline PAR & & & & 0.28 & 0.04 & 0.00 & -0.04 & 0.01 & 0.00 & & & & & & \\
\hline PD & -0.16 & 0.03 & 0.00 & -0.09 & 0.04 & 0.02 & & & & 0.46 & 0.05 & 0.00 & & & \\
\hline BD & & & & & & & & & & -0.55 & 0.07 & 0.00 & -0.24 & 0.06 & 0.00 \\
\hline C & & & & & & & & & & & & & 0.17 & 0.05 & 0.00 \\
\hline $\mathrm{CN}$ & & & & -0.10 & 0.04 & 0.02 & & & & & & & & & \\
\hline Sh & 0.17 & 0.03 & 0.00 & & & & 0.03 & 0.01 & 0.01 & -0.59 & 0.05 & 0.00 & & & \\
\hline Mo & -0.18 & 0.03 & 0.00 & & & & & & & & & & & & \\
\hline $\mathrm{T} * \mathrm{WT}$ & -0.11 & 0.03 & 0.00 & & & & & & & & & & & & \\
\hline $\mathrm{T}^{*} \mathrm{PD}$ & -0.14 & 0.03 & 0.00 & -0.12 & 0.04 & 0.00 & & & & & & & & & \\
\hline $\mathrm{T} * \mathrm{BD}$ & & & & & & & & & & & & & 0.14 & 0.03 & 0.00 \\
\hline $\mathrm{T}^{*} \mathrm{CN}$ & & & & -0.18 & 0.04 & 0.00 & & & & & & & & & \\
\hline $\mathrm{T} * \mathrm{Sh}$ & 0.07 & 0.03 & 0.02 & & & & & & & & & & & & \\
\hline $\mathrm{T}^{*} \mathrm{Se}$ & & & & 0.11 & 0.04 & 0.01 & & & & & & & & & \\
\hline T*Mo & -0.07 & 0.03 & 0.02 & & & & & & & & & & & & \\
\hline WT*PAR & & & & & & & -0.04 & 0.01 & 0.00 & & & & & & \\
\hline WT*Se & & & & 0.10 & 0.05 & 0.03 & -0.04 & 0.01 & 0.00 & & & & & & \\
\hline $\mathrm{PD} * \mathrm{Sh}$ & & & & & & & & & & -0.16 & 0.06 & 0.01 & & & \\
\hline $\mathrm{BD}^{*} \mathrm{C}$ & & & & & & & & & & -0.33 & 0.07 & 0.00 & -0.10 & 0.04 & 0.02 \\
\hline $\mathrm{BD}^{*} \mathrm{CN}$ & & & & & & & & & & -0.34 & 0.07 & 0.00 & & & \\
\hline $\mathrm{BD} * \mathrm{Se}$ & & & & & & & & & & -0.40 & 0.08 & 0.00 & & & \\
\hline $\mathrm{BD} * \mathrm{Mo}$ & & & & & & & & & & -0.25 & 0.07 & 0.00 & & & \\
\hline $\mathrm{C}^{*} \mathrm{CN}$ & & & & & & & & & & & & & 0.07 & 0.03 & 0.04 \\
\hline$C * S h$ & & & & & & & & & & 0.24 & 0.06 & 0.00 & & & \\
\hline $\mathrm{C} * \mathrm{Se}$ & & & & & & & & & & -0.39 & 0.08 & 0.00 & & & \\
\hline $\mathrm{C} * \mathrm{Mo}$ & & & & & & & & & & -0.33 & 0.08 & 0.00 & & & \\
\hline $\mathrm{CN} * \mathrm{Sh}$ & & & & -0.12 & 0.05 & 0.01 & & & & & & & & & \\
\hline $\mathrm{CN} * \mathrm{Se}$ & & & & -0.18 & 0.05 & 0.00 & & & & & & & & & \\
\hline $\mathrm{Sh} * \mathrm{Se}$ & & & & -0.40 & 0.06 & 0.00 & 0.04 & 0.01 & 0.01 & -0.71 & 0.07 & 0.00 & & & \\
\hline $\mathrm{Sh} * \mathrm{Mo}$ & 0.16 & 0.03 & 0.00 & 0.20 & 0.04 & 0.00 & & & & 0.21 & 0.05 & 0.00 & & & \\
\hline$\sum$ main & 1.16 & & & 1.11 & & & 0.07 & & & 1.60 & & & 0.73 & & \\
\hline Einter & 0.55 & & & 1.41 & & & 0.12 & & & 3.35 & & & 0.31 & & \\
\hline
\end{tabular}

Factors and interactions not shown here were not significant in any of the models.

$T=$ temperature $; T$ W water table depth; $P A R=$ photosynthetically active radiation; $P D=$ peat depth; BD = bulk density; $C=\%$ carbon; $N=\% N ; C N=C: N ;$ Sh = shrub biomass; Se = sedge biomass; Mo = moss biomass; * denotes an interaction; $R^{2}=$ pseudo $R^{2} ; \sum$ main $=$ sum of the main effect coefficients (absolute values); $\sum$ inter $=$ sum of the interaction coefficients (absolute values).

the lowest bulk density, and intermediate peat depth (Tables 3, 4).

Biomass and water table were the only factors that varied significantly with PFT, although for water table the effects of site and season were greater (Table 3). We found that shrubs had the greatest biomass and mosses the lowest and the water table was deepest under shrubs and shallowest under mosses (Table 4).

On average the dominant PFT constituted 65, 84, and $84 \%$ of the total biomass in the shrub-, sedge-, and moss-dominated plots, respectively. Within plots they dominated, sedges and mosses comprised a minimum of $65-70 \%$ of the total biomass, respectively, and with the exception of four plots (within which the shrubs died off and thus the biomass was not included), the shrub dominated plots had a minimum shrub biomass of $60 \%$ of the total.

Unsurprisingly season explained most variance in $R_{\text {eco }}, P_{\text {cal }}$, and NEE: $R_{\text {eco }}$ and $P_{\text {cal }}$ were lowest in winter and highest in summer and, on balance, most $\mathrm{C}$ was sequestered in the autumn (that is, NEE was negative) (Tables 1, 5; Figure 1). For 

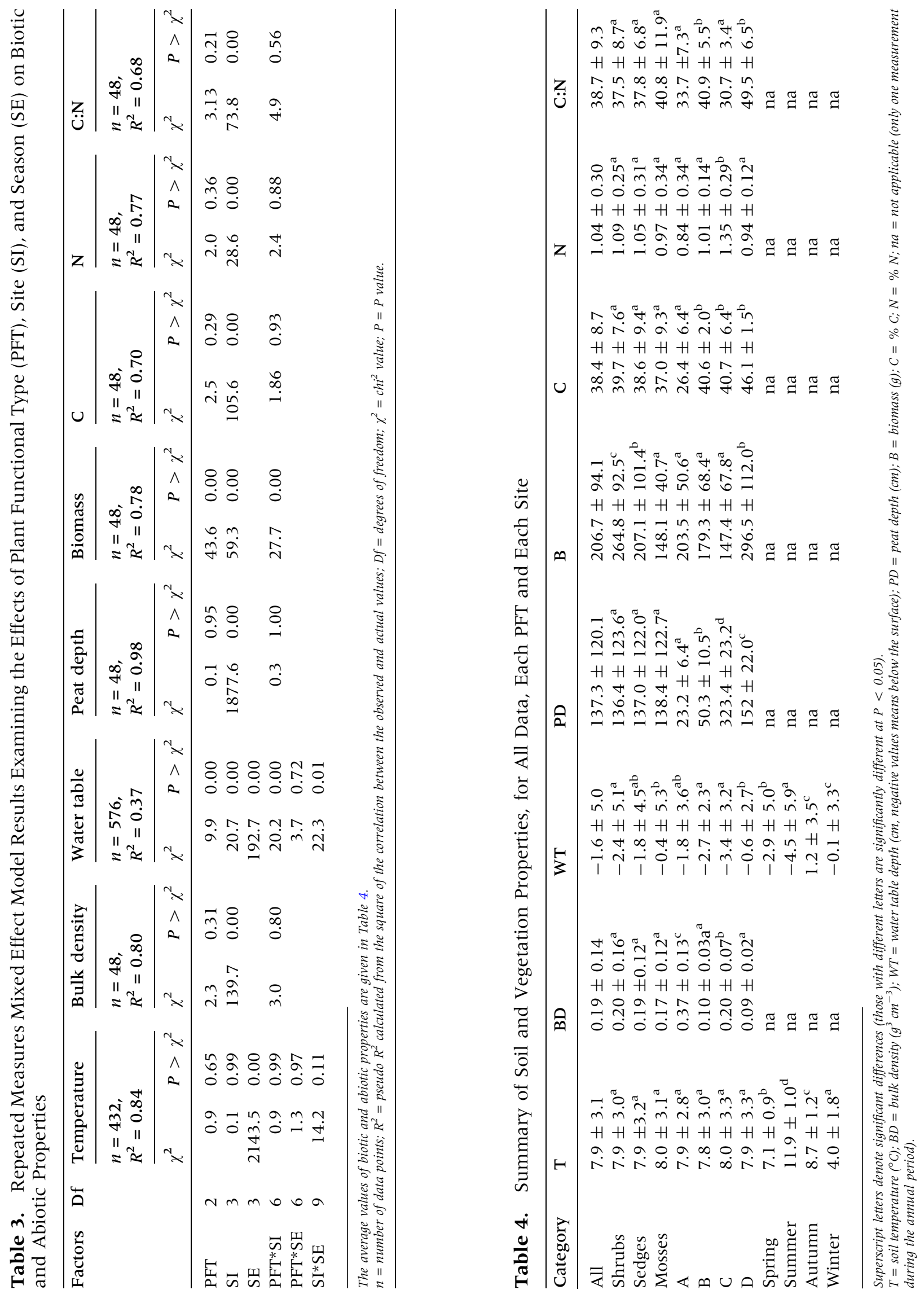
[DOC], season also dominated, with concentrations generally increasing from winter through to autumn (Tables 1, 5; Figure 1). In contrast season explained the least variance in $\mathrm{CH}_{4}$ fluxes, with $\mathrm{CH}_{4}$ peaking in autumn (Table 1, 5; Figure 1). Season also interacted with PFT for all models except $\mathrm{CH}_{4}$ and [DOC] and interacted with the variation in properties integrated by site for all models except $\mathrm{CH}_{4}$ (Table 1). For example, $R_{\text {eco }}$ increased in magnitude and variability in shrub and sedge plots in the summer, while rates from moss plots remained relatively low throughout the year (Figure 1).

PFT explained more variation in $R_{\text {eco }}$ and $P_{\text {cal }}$ than the variation in properties integrated by site; $R_{\text {eco }}$ and $P_{\text {cal }}$ were significantly greater and more variable from shrubs and sedges than mosses (Table 1, 5; Figure 1). Mosses were generally a sink of $\mathrm{CO}_{2}$, sedges were the largest sink (although they were predominantly weak sources during winter) and shrubs were the largest source (especially during the summer months) (Table 5, Figure 1). PFT explained the least variance in $\mathrm{CH}_{4}$ fluxes, with greater and more variable $\mathrm{CH}_{4}$ fluxes from sedges compared with shrubs and mosses (Table 5; Figure 1). PFT was not significant as an individual driver for [DOC] (Table 1).

Spatial differences in GHG fluxes and [DOC] were also evident, with site having the smallest effect for $R_{\text {eco }}$ and $P_{\text {cal }}$, the largest effect for $\mathrm{CH}_{4}$ and an intermediate effect for [DOC] (Table 1). $\mathrm{CO}_{2}$ fluxes were broadly similar across sites with some significant differences driven by greater variability during the spring and summer (Figure 1; Table 5). Specifically, $R_{\text {eco }}$ was greater at site B than site C with differences most apparent in the summer, $P_{\text {cal }}$ was higher (that is, greater $\mathrm{CO}_{2}$ uptake but lower values as $P_{\text {cal }}$ is negative) at site A than $\mathrm{C}$, most notably during the spring and less $\mathrm{C}$ was sequestered at site B compared with sites A and C, especially during the summer (Table 5; Figure 1). Sites $\mathrm{A}$ and $\mathrm{B}$ had significantly lower $\mathrm{CH}_{4}$ fluxes than $\mathrm{C}$ and D (Tables 4, 5; Figure 1). Finally, [DOC] generally increased from site A to D although site B had similar [DOC] to sites C and D (Table 5).

\section{The Importance of Interactions}

Interactions explained more of the variance in $P_{\mathrm{cal}}$, $\mathrm{NEE}$, and $\mathrm{CH}_{4}$ than individual drivers and contributed notably to $R_{\text {eco }}$ and [DOC], as indicated by the sum of the main and interactive effect coefficients (Table 2).The majority of the interactive drivers for $R_{\text {eco }}$ included temperature, with the response rate (that is, change in $R_{\text {eco }}$ for a unit increase in temperature) increasing with temperature at a greater rate at deeper water table depths, shallower peat depths, lower moss biomass, and higher shrub biomass (Table 2; Figure 2A). Out of the interactive drivers, the shrub-moss interaction had the greatest effect for $R_{\text {eco; }}$ ecosystem respiration was positively related to shrub biomass but increased to a greater extent where moss biomass was also high (Figure 2B). Temperature did not interact with as many drivers for $P_{\text {cal }}$; instead the majority of interactions featured a biotic variable (Table 2). The shrub-sedge interaction was dominant with the effect size (as indicated by the coefficient) double that of any other interactions (Table 2). $P_{\text {cal }}$ decreased with increasing shrub

Table 5. Average \pm Standard Deviation $R_{\text {eco }}\left(\mathrm{mg} \mathrm{C} \mathrm{m}^{-2} \mathrm{~h}^{-1}\right), P_{\text {cal }}\left(\mathrm{mg} \mathrm{C} \mathrm{m}^{-2} \mathrm{~h}^{-1}\right)$, NEE $\left(\mathrm{mg} \mathrm{C} \mathrm{m}^{-2} \mathrm{~h}^{-1}\right)$, $\mathrm{CH}_{4}\left(\mathrm{mg} \mathrm{C} \mathrm{m}^{-2} \mathrm{~h}^{-1}\right)$, and [DOC] $\left(\mathrm{mg} \mathrm{l}^{-1}\right)$ for the Different PFT, Sites (A-D), and Seasons

\begin{tabular}{lclccc}
\hline Factors & $R_{\text {eco }}$ & $P_{\text {cal }}$ & NEE & CH $_{4}$ & {$[$ DOC] } \\
\hline All & $156.3 \pm 223.3$ & $-225.3 \pm 228.0$ & $-46.0 \pm 196.9$ & $0.96 \pm 1.54$ & $45.0 \pm 30.4$ \\
Shrubs & $205.1 \pm 295.2^{\mathrm{b}}$ & $-254.1 \pm 242.3^{\mathrm{a}}$ & $-14.2 \pm 255.0^{\mathrm{b}}$ & $0.50 \pm 1.19^{\mathrm{a}}$ & $45.1 \pm 28.4^{\mathrm{a}}$ \\
Sedges & $182.4 \pm 163.7^{\mathrm{b}}$ & $-299.6 \pm 259.5^{\mathrm{a}}$ & $-90.4 \pm 210.3^{\mathrm{a}}$ & $1.75 \pm 1.79^{\mathrm{b}}$ & $45.2 \pm 30.4^{\mathrm{a}}$ \\
Mosses & $75.7 \pm 101.7^{\mathrm{a}}$ & $-122.3 \pm 117.6^{\mathrm{b}}$ & $-34.9 \pm 67.8^{\mathrm{b}}$ & $0.65 \pm 1.28^{\mathrm{a}}$ & $44.7 \pm 32.4^{\mathrm{a}}$ \\
A & $172.0 \pm 212.0^{\mathrm{ab}}$ & $-279.6 \pm 247.6^{\mathrm{a}}$ & $-77.0 \pm 185.9^{\mathrm{a}}$ & $0.54 \pm 1.21^{\mathrm{a}}$ & $29.1 \pm 28.8^{\mathrm{a}}$ \\
B & $211.4 \pm 319.3^{\mathrm{b}}$ & $-226.0 \pm 219.4^{\mathrm{ab}}$ & $5.2 \pm 248.8^{\mathrm{b}}$ & $0.34 \pm 0.82^{\mathrm{a}}$ & $50.2 \pm 34.3^{\mathrm{bc}}$ \\
C & $108.7 \pm 161.1^{\mathrm{a}}$ & $-196.9 \pm 235.0^{\mathrm{b}}$ & $-69.3 \pm 164.0^{\mathrm{a}}$ & $1.26 \pm 1.55^{\mathrm{b}}$ & $41.5 \pm 20.9^{\mathrm{b}}$ \\
D & $134.9 \pm 151.4^{\mathrm{ab}}$ & $-200.8 \pm 200.2^{\mathrm{ab}}$ & $-42.3 \pm 167.7^{\mathrm{ab}}$ & $1.98 \pm 2.00^{\mathrm{b}}$ & $56.7 \pm 28.3^{\mathrm{c}}$ \\
Spring & $128.2 \pm 84.9^{\mathrm{c}}$ & $-176.9 \pm 139.3^{\mathrm{b}}$ & $-47.9 \pm 125.1^{\mathrm{b}}$ & $0.87 \pm 1.52^{\mathrm{a}}$ & $39.5 \pm 19.6^{\mathrm{b}}$ \\
Summer & $322.1 \pm 365.1^{\mathrm{d}}$ & $-360.0 \pm 289.8^{\mathrm{a}}$ & $-23.7 \pm 292.1^{\mathrm{b}}$ & $0.98 \pm 1.60^{\mathrm{a}}$ & $53.8 \pm 34.9^{\mathrm{c}}$ \\
Autumn & $118.5 \pm 104.9^{\mathrm{b}}$ & $-244.4 \pm 226.2^{\mathrm{b}}$ & $-108.1 \pm 194.3^{\mathrm{a}}$ & $1.35 \pm 1.85^{\mathrm{b}}$ & $59.3 \pm 32.0^{\mathrm{d}}$ \\
Winter & $43.9 \pm 36.9^{\mathrm{a}}$ & $-86.6 \pm 103.7^{\mathrm{c}}$ & $-4.0 \pm 108.0^{\mathrm{b}}$ & $0.64 \pm 1.02^{\mathrm{a}}$ & $27.4 \pm 21.5^{\mathrm{a}}$
\end{tabular}

Significant differences occurred between those with different superscript letters. 

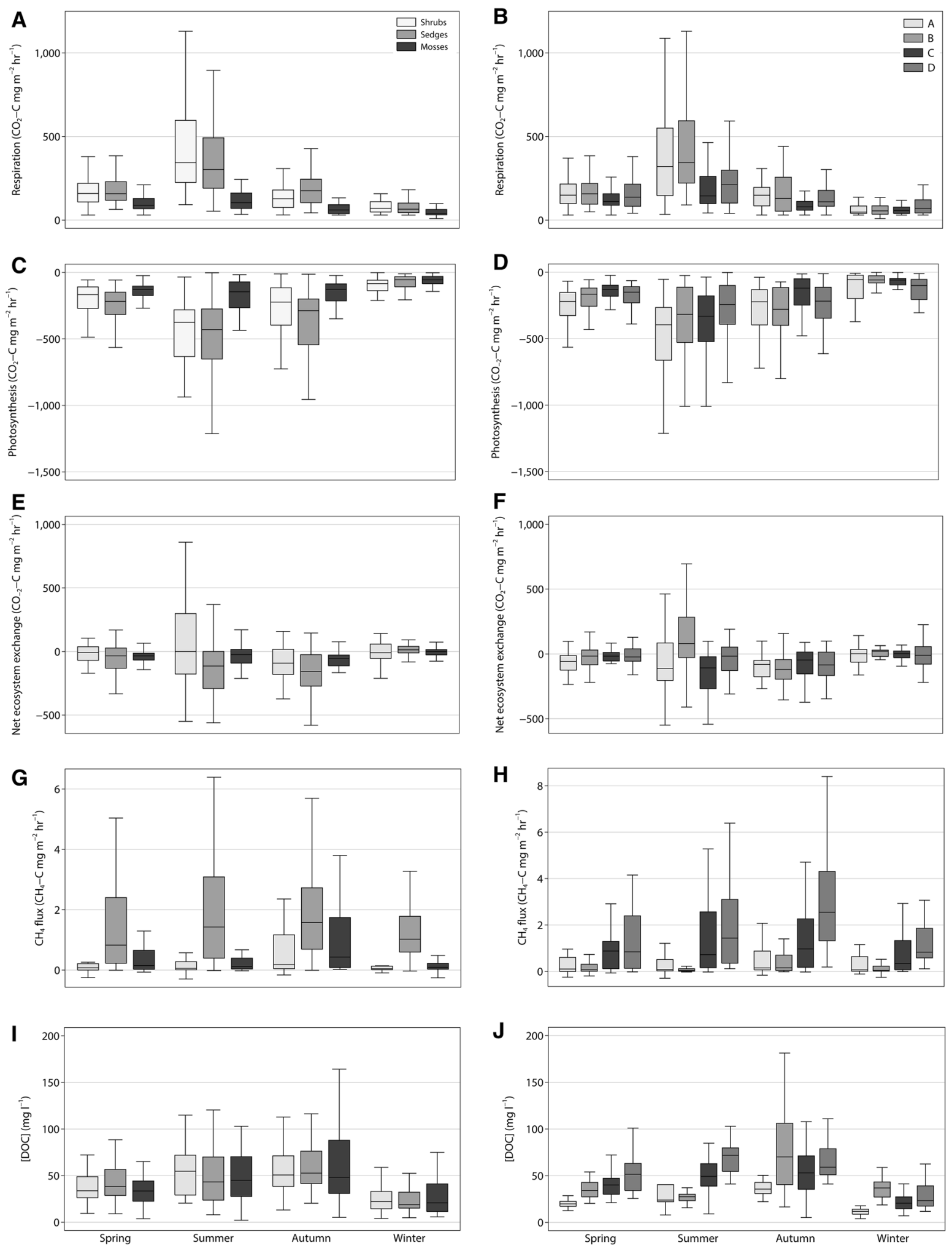

Figure 1. Variation in $R_{\text {eco }}(\mathbf{A}, \mathbf{B}), P_{\text {cal }}(\mathbf{C}, \mathbf{D})$, NEE $(\mathbf{E}, \mathbf{F}), \mathrm{CH}_{4}$ flux $(\mathbf{G}, \mathbf{H})$, and [DOC] $(\mathbf{I}, \mathbf{J})$ with PFT (shrub, sedge, and moss $(\mathbf{A}, \mathbf{C}, \mathbf{E}, \mathbf{G}, \mathbf{I})$ and site $(\mathbf{A}-\mathbf{D})(\mathbf{B}, \mathbf{D}, \mathbf{F}, \mathbf{H}, \mathbf{J})$ throughout the year. Negative values represent transfer from the atmosphere (sink) and positive values to the atmosphere (source). The upper whiskers on these plot represent the data point that is $\leq 75$ th percentile $+(75$ th percentile -25 th percentile $) \times 1.5$ and the lower whisker the data point that is $\leq 25$ th percentile $-(75$ th percentile -25 th percentile $) \times 1.5$ 

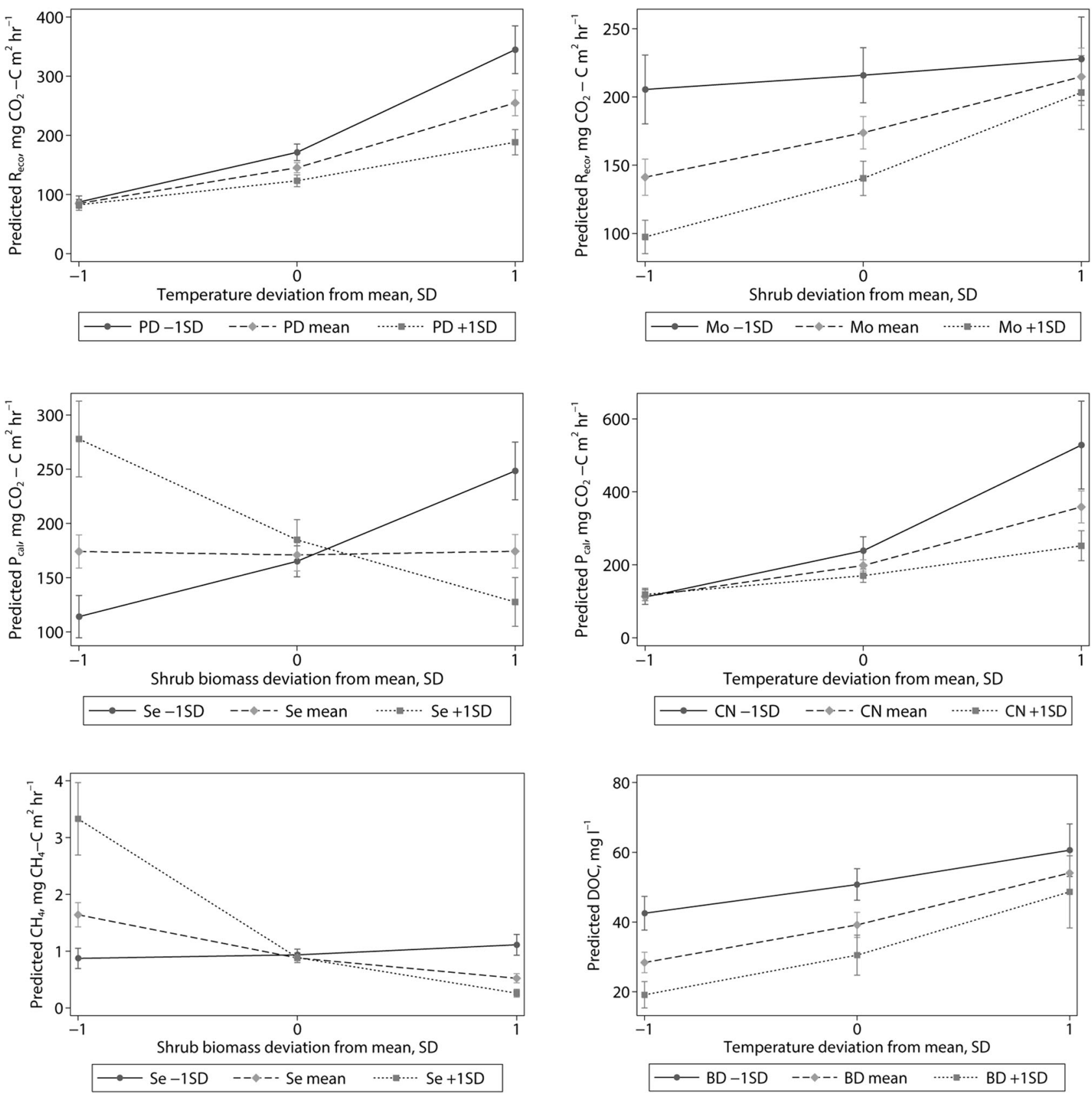

Figure 2. Interaction plots for the $R_{\mathrm{eco}}, P_{\mathrm{cal}}, \mathrm{CH}_{4}$, and [DOC] GLM models. The plots are for the transformed data and thus $0=$ the mean of the biotic or abiotic property, -1 is one standard deviation below the mean and 1 is one standard deviation above the mean, and $P_{\text {cal }}$ has been multiplied by -1 . SD = standard deviation; $P D=$ peat depth; Mo = moss biomass; $\mathrm{Se}=$ sedge biomass; $C N=\mathrm{C}: \mathrm{N} ; B D=$ bulk density

biomass at high sedge biomass, increased at low sedge biomass, and remained constant with mean sedge biomass (Figure 2C). As for $R_{\mathrm{eco}}$, the rate of increase in $P_{\text {cal }}$ with temperature was greater at shallower peat depths and also at lower C:N (Figure 2D).

For $\mathrm{CH}_{4}$, as for $P_{\text {cal }}$, the shrub-sedge interaction explained the most variance (and dominated over the individual drivers) (Table 2). $\mathrm{CH}_{4}$ flux decreased with increasing shrub biomass and at a greater rate when sedge biomass was higher. However, at sites with the lowest sedge biomass, $\mathrm{CH}_{4}$ flux increased with increasing shrub biomass (Figure 2E). The other dominant interactions for $\mathrm{CH}_{4}$ included peat $\mathrm{C}$ and bulk density (Table 2). $\mathrm{CH}_{4}$ decreased with bulk density at a faster rate if 
peat $\mathrm{C}$ was lower or if $\mathrm{C}: \mathrm{N}$ or sedge biomass was higher. $\mathrm{CH}_{4}$ fluxes did not vary with peat $\mathrm{C}$ if sedge or shrub biomass was intermediate. However, at higher sedge and lower shrub biomass, $\mathrm{CH}_{4}$ fluxes decreased with increasing peat $\mathrm{C}$ and vice versa.

Compared to GHG fluxes, interactions were not as important for [DOC], both in terms of the number and effect size (Table 2). The dominant interaction was temperature-bulk density, with [DOC] increasing with rising temperatures at a greater rate at higher bulk densities (Figure 2F). [DOC] also increased with increasing peat $\mathrm{C}$ but at lower rates at the higher bulk densities.

\section{Discussion}

Our field experiment was designed to examine the individual and interactive effects of critical biotic and abiotic drivers of plant peat $\mathrm{C}$ cycling across a blanket peatland located in Scotland, UK. Results demonstrate the high spatio-temporal variability in peatland C cycling (that is, $R_{\mathrm{eco}}, P_{\mathrm{cal}}, \mathrm{NEE}, \mathrm{CH}_{4}$ fluxes, and pore water [DOC]) with season, dominant PFT, and locations across the peatland (Table 1). Our first hypothesis, that PFT would explain more of the variance in GHG fluxes and [DOC] than the integrated effect of location within the peatland (site), was supported for $R_{\text {eco }}$ and $P_{\text {cal }}$ (Table 1). However, site explained more variation in $\mathrm{CH}_{4}$ fluxes and DOC than PFT (Table 1). Our second hypothesis that interactions explained a significant proportion of the variance in GHG fluxes and [DOC] was supported (Tables 1, 2).

\section{The Importance of Season, PFT, and the Integrated Effect of Spatially Varying Properties}

The northern latitude of Black Law wind farm promoted a strong seasonal cycle, with both temperature and water table dominated by seasonal effects (Tables 1,3). Consequently, $\mathrm{CO}_{2}$ fluxes and [DOC] showed strong seasonality: the lowest $\mathrm{CO}_{2}$ fluxes were observed during the winter months, when low temperatures suppressed photosynthesis and decomposition processes, and the highest fluxes occurred during summer, when biological processes were promoted by warmer temperatures (Clark and others 2005; Bonnett and others 2006). Pore water [DOC] did not peak until autumn, attributable to the relatively high temperatures in summer and autumn that promoted decomposition and mobilization into the dissolved phase in autumn when the water table rose (Tables 4, 5) (Grayson and Holden 2012). $\mathrm{CH}_{4}$ also peaked in autumn, which coincided with relatively high water tables and temperature (including at depth) (Tables 4 ,5). The relatively high autumnal water tables and temperatures may have promoted greater methanogen activity $\left(\mathrm{CH}_{4}\right.$ production) and limited methanotroph activity $\left(\mathrm{CH}_{4}\right.$ oxidation), leading to the higher $\mathrm{CH}_{4}$ fluxes (Moore and others 2011; Dijkstra and others 2012; van Winden and others 2012). Further, long $\mathrm{CH}_{4}$ residence times may have promoted the accumulation of a large $\mathrm{CH}_{4}$ pool by autumn (Kellner and others 2005; Strack and others 2008).

PFT which, as hypothesized, dominated over the integrated effect of site for $\mathrm{CO}_{2}$ fluxes (but not $\mathrm{CH}_{4}$ or $[\mathrm{DOC}])$, has been shown to influence peatland $\mathrm{C}$ cycling due to the direct and indirect effects of different traits (for example, physiological, phenological, and ecological) (Ward and others 2009, 2013). In this study, there were significant effects of PFT on $\mathrm{CO}_{2}$ fluxes with $R_{\text {eco }}$ and $P_{\text {cal }}$ rates lower in moss-dominated plots than from shrub and sedge plots (Table 5). This is unsurprising due to their lower biomass, less efficient photosynthesis, lower litter quality, and the production of secondary metabolites which are known to inhibit decomposition (Turetsky 2003; Marschall and Proctor 2004; Toet and others 2006). However, water table depth may also be playing a role: depth to the water table was significantly greater at shrub plots compared with moss plots (Table 4 ). The $R_{\text {eco }}$ and $P_{\text {cal }}$ rates of moss plots were less responsive to seasonal change compared with sedges and shrubs, as mosses are active throughout the year, whereas vascular plants have a defined growing season (Figure 1). The dominance of PFT indicates the pivotal role of plant communities in influencing peatland $\mathrm{C}$ balances and the potential implications of both natural and managed vegetation change.

PFT explained the second largest amount of variation in the $\mathrm{CH}_{4}$ fluxes (site dominated), with higher fluxes associated with sedges (Tables 1, 5). Sedges possess aerenchyma (a morphological trait that shrubs and mosses do not possess), which act as a conduit between the soil and atmosphere. Aerenchyma prevent oxidation of $\mathrm{CH}_{4}$, which typically occurs in aerobic layers of peat, although they can also transport oxygen into the anoxic zone, and thus promote $\mathrm{CH}_{4}$ oxidation in the rhizosphere (Levy and others 2012; Bhullar and others 2013). Further, differences in root exudate quality (for example, organic acid concentrations) between the different PFTs may contribute to the higher $\mathrm{CH}_{4}$ fluxes from sedges (Ström and others 2012). As the water table depth was not significantly different under sedges compared with mos- 
ses and shrubs (Table 4), we infer that oxidation potential within the peat profile did not play a role in the differences in $\mathrm{CH}_{4}$ fluxes.

There was no relationship between PFT and [DOC], despite the influence of plant functional traits on physical and biological conditions that regulate [DOC] (Armstrong and others 2012). At Black Law the vegetation was a very patchy mosaic of shrubs, sedges, and mosses, and thus the physical and biological effects of the PFTs at a sampling point would be less apparent compared with other peatlands at which the vegetation occurred in larger patches and [DOC] was found to be significantly correlated with PFT (Armstrong and others 2012).

The integrated effect of site was significant for all GHG fluxes and [DOC], although less dominant than season and PFT for $R_{\text {eco }}$ and $P_{\text {cal }}$, and less dominant than season for [DOC] (Table 1). Within site differences can be more important than temporal (inter-annual) controls on $\mathrm{C}$ cycling in peatlands and thus understanding of the underlying mechanisms is crucial (Waddington and Roulet 2000). Spatial differences in C cycling will be influenced by variation in the driving biotic and abiotic properties. At Black Law, both relatively static (bulk density, peat depth, C, N, and C:N) and dynamic properties (water table and biomass) varied significantly with site (Tables 3, 4). Further, site will have incorporated other unmeasured static and dynamic spatially variable characteristics (for example, microbial community metrics (Schmidt and others 2007)), known to influence C cycling. Resolving the role and interaction between these static and dynamic, biotic, and abiotic characteristics is necessary to infer the effects of environmental change on peatland $\mathrm{C}$ cycling, especially for [DOC] and $\mathrm{CH}_{4}$ fluxes.

\section{The Importance of Interactions}

The statistical modeling demonstrated that biotic and abiotic factors had individual and interactive effects on peatland $\mathrm{C}$ cycling and that their relative importance varied among $R_{\text {eco }}, P_{\text {cal }}, \mathrm{CH}_{4}$ fluxes, and [DOC] (Table 2). Although these models indicated that the effect sizes of the individual drivers were generally greater than those of the interactions, together the interactions explained more variance in $P_{\text {cal }}, \mathrm{NEE}$, and $\mathrm{CH}_{4}$ than individual drivers, and the variation in $R_{\text {eco }}$ and [DOC] explained by the interactions was not inconsequential (Table 2). Consequently, our second hypothesis, that interactions would explain a significant proportion of the variance in GHG fluxes and [DOC] was sup- ported. Our analysis also highlighted thresholds in interactions. For example, $P_{\text {cal }}$ decreased with increasing shrub biomass when sedge biomass was high, was constant when sedge biomass was average, and increased when sedge biomass was low. Such thresholds further indicate the complexity of $\mathrm{C}$ cycling in peatlands and the need to develop understanding of interactive effects.

Interactions with temperature were key for $\mathrm{CO}_{2}$ fluxes (Table 2), suggesting that there is potential for the response to global warming to be exacerbated, or mediated, by the concomitant variation in biotic and abiotic conditions. The interactions with temperature may also explain why temperature sensitivities are highly variable between studies/ treatments (Davidson and Janssens 2006). There were synergistic effects between temperature and shrubs for $R_{\text {eco }}$ and temperature and sedge for $P_{\text {cal }}$ (Table 2). The synergistic effect between temperature and shrubs is concerning with regard to peat $\mathrm{C}$ storage given the observed and projected increase in both in some systems (Sturm and others 2001). Further, the interactions between temperature and water table, peat depth, shrub and moss biomass for $R_{\mathrm{eco}}$, and temperature and peat depth and C:N for $P_{\text {cal }}$, suggest that the sensitivity of $R_{\text {eco }}$ and $P_{\text {cal }}$ to these factors may increase under a warmer climate and that response between peatlands and different sites within a peatland may diverge.

For all GHG fluxes, there was either an interaction between shrub and sedge biomass or shrub and moss biomass, with the effect sizes, as indicated by the coefficient size, among the largest for the interactions (Table 2). This indicates the key role that PFT plays in peatland $\mathrm{C}$ cycling and also indicates the importance of plant community composition. The centrality of PFT may reflect direct effects, such as photosynthesis rates given leaf area, or indirect effects, such as different decomposition rates due to litter and root exudation characteristics and microbial communities associated with each PFT (Crow and Wieder 2005; Moore and others 2007; Bardgett and van der Putten 2014). The biomass of the PFTs also interacted with a range of abiotic factors, including climatic and peat property variables (Table 2). Previously, plant removal experiments have shown that warming effects on $R_{\text {eco }}$ did not differ between PFTs (Ward and others 2013). In contrast, we found that the $R_{\text {eco }}$ response to temperature increased at higher shrub and lower moss biomass, although our analysis is based on seasonal temperature changes, whereas Ward and others had a warming treatment (Table 2). The interactions between temperature and shrub and moss biomass likely indicate the indirect effects of 
PFT on $\mathrm{C}$ cycling. For example, the weaker response of $R_{\text {eco }}$ to increasing temperature at high moss biomass may reflect the inhibiting role of secondary metabolites and low $\mathrm{N}$, both of which are associated with Sphagnum (Turetsky and others 2008). Further, microbial taxa are associated with specific PFTs and their response to temperature, and thus decomposition rates, may vary (Bardgett and van der Putten 2014).

The importance and nature of the interactions indicates that under future environmental change, components of the system, which together determine the $\mathrm{C}$ balance of the peatland, may respond in different ways. PFT biomass interacted with both biotic and abiotic factors, to affect GHG fluxes and [DOC] demonstrating the centrality of vegetation to peatland $\mathrm{C}$ cycling. $\mathrm{CO}_{2}$ fluxes were dominated by interactions including temperature, thus signaling an immediate response to climate warming. In contrast, interactions including peat physical and chemical properties were more important for $\mathrm{CH}_{4}$ and [DOC] suggesting that immediate effects could occur in response to land management that affects peat physical and chemical properties (including fertilization and compaction through vehicle access). In addition there may also be longer term effects on $\mathrm{CH}_{4}$ fluxes and [DOC] in response to indirect feedbacks to environmental change (including change in litter quality). These varying responses to drivers that change over different time scales and interact make projection of the composite effect of environmental change on peatland C cycling complex.

\section{Conclusions}

Resolving the relative role of biotic and abiotic factors, including interactions, on globally important northern peatlands is central to predicting their contribution to mediating or exacerbating climate change. The number and strength of the interactions in the models used here and the presence of thresholds indicates the need for multivariate experiments within which the roles of interactions are explicitly tested. Without understanding the interactions between and within biotic and abiotic factors, it is difficult to predict the effects of future change on peatland $\mathrm{C}$ cycling, or translate results between sites with different characteristics. The interactions highlighted in this field experiment, within which biotic and abiotic factors varied naturally, suggest future research should be focussed on temperature interactions for $\mathrm{CO}_{2}$ fluxes, bulk density, and peat $\mathrm{C}$ concentration for $\mathrm{CH}_{4}$ and [DOC], and PFT for all components. Such studies will include spatially and temporally extensive assessment of $\mathrm{C}$ cycling in field environments, but also controlled laboratory studies examining the interactions highlighted in this study.

\section{ACKNOWLEDGEMENTS}

This research was supported by NERC, NE/ H010351/1. Alona Armstrong acknowledges support from an Energy Lancaster fellowship to bring the paper to completion. We thank Scottish Power, especially Kenny Bryce, and the landowners for access to the field site. Anne-Laure Berthod, Andy Cole, Jess Davies, Dafydd Elias, Rachel Marshall, Kelly Mason, Magdalena Matysek, Simon Oakley, Kenny Roberts, Andy Robertson, Ben Smith, Tom Walker, and Mike Whitfield all assisted in the field. Emma Eastoe helped with statistical queries. All data associated with this study are available from the CEH Environmental Information Platform (https://eip.ceh.ac.uk/) and the data have been allocated a digital object identifier (http://doi.org/ 10/7tj and http://doi.org/10/6zs).

\section{OPEN ACCESS}

This article is distributed under the terms of the Creative Commons Attribution 4.0 International License (http://creativecommons.org/licenses/by/ 4.0/), which permits unrestricted use, distribution, and reproduction in any medium, provided you give appropriate credit to the original author(s) and the source, provide a link to the Creative Commons license, and indicate if changes were made.

\section{REFERENCES}

Aerts R, Chapin FS. 1999. The mineral nutrition of wild plants revisited: a re-evaluation of processes and patterns. In: Fitter AH, Raffaelli DG, Eds. Advances in ecological research. San Diego: Academic Press. p 1-67.

Armstrong A, Holden J, Kay P, Francis B, Foulger M, Gledhill S, McDonald AT, Walker A. 2010. The impact of peatland drainblocking on dissolved organic carbon loss and discolouration of water; results from a national survey. J Hydrol 381:112-20.

Armstrong A, Holden J, Luxton K, Quinton JN. 2012. Multiscale relationship between peatland vegetation type and dissolved organic carbon concentration. Ecol Eng 47:182-8.

Baird AJ, Beckwith CW, Waldron S, Waddington JM. 2004. Ebullition of methane-containing gas bubbles from near-surface Sphagnum peat. Geophys Res Lett 31:L21505.

Bardgett RD, Freeman C, Ostle NJ. 2008. Microbial contributions to climate change through carbon cycle feedbacks. ISME J 2:805-14.

Bardgett RD, van der Putten WH. 2014. Belowground biodiversity and ecosystem functioning. Nature 515:505-11. 
Bhullar G, Iravani M, Edwards P, Olde Venterink H. 2013. Methane transport and emissions from soil as affected by water table and vascular plants. BMC Ecol 13:32.

Billett MF, Harvey FH. 2013. Measurements of $\mathrm{CO}_{2}$ and $\mathrm{CH}_{4}$ evasion from UK peatland headwater streams. Biogeochemistry 114:165-81.

Blodau C, Basiliko N, Moore TR. 2004. Carbon turnover in peatland mesocosms exposed to different water table levels. Biogeochemistry 67:331-51.

Bonnett SAF, Ostle N, Freeman C. 2006. Seasonal variations in decomposition processes in a valley-bottom riparian peatland. Sci Total Environ 370:561-73.

Bragazza L, Bardgett RD, Mitchell EAD, Buttler A. 2014. Linking soil microbial communities to vascular plant abundance along a climate gradient. New Phytol 205(3):1175-82.

Bragazza L, Buttler A, Habermacher J, Brancaleoni L, Gerdol R, Fritze H, Hanajík P, Laiho R, Johnson D. 2012. High nitrogen deposition alters the decomposition of bog plant litter and reduces carbon accumulation. Glob Change Biol 18:1163-72.

Bragazza L, Freeman C, Jones T, Rydin H, Limpens J, Fenner N, Ellis T, Gerdol R, Hájek M, Hájek T, Iacumin P, Kutnar L, Tahvanainen T, Toberman H. 2006. Atmospheric nitrogen deposition promotes carbon loss from peat bogs. Proc Natl Acad Sci 103:19386-9.

Bragazza L, Parisod J, Buttler A, Bardgett RD. 2013. Biogeochemical plant-soil microbe feedback in response to climate warming in peatlands. Nat Clim Change 3:273-7.

Bubier JL, Bhatia G, Moore TR, Roulet NT, Lafleur PM. 2003. Spatial and temporal variability in growing-season net ecosystem carbon dioxide exchange at a large peatland in Ontario, Canada. Ecosystems 6:353-67.

Bubier JL, Moore TR, Bledzki LA. 2007. Effects of nutrient addition on vegetation and carbon cycling in an ombrotrophic bog. Glob Change Biol 13:1168-86.

Carter MR, Gregorich EG. 2007. Soil sampling and methods of analysis. Boca Raton: CRC Press.

Christiansen J, Korhonen JJ, Juszczak R, Giebels M, Pihlatie M. 2011. Assessing the effects of chamber placement, manual sampling and headspace mixing on $\mathrm{CH}_{4}$ fluxes in a laboratory experiment. Plant Soil 343:171-85.

Clark JM, Ashley D, Wagner M, Chapman PJ, Lane SN, Evans CD, Heathwaite AL. 2009. Increased temperature sensitivity of net DOC production from ombrotrophic peat due to water table draw-down. Glob Change Biol 15:794-807.

Clark JM, Chapman PJ, Adamson JK, Lane SN. 2005. Influence of drought-induced acidification on the mobility of dissolved organic carbon in peat soils. Glob Change Biol 11:791-809.

Clark JM, Lane SN, Chapman PJ, Adamson JK. 2008. Link between DOC in near surface peat and stream water in an upland catchment. Sci Total Environ 404:308-15.

Crow SE, Wieder RK. 2005. Sources of CO2 emission from a northern peatland: root respiration, exudation, and decomposition. Ecology 86:1825-34.

Davidson EA, Janssens IA. 2006. Temperature sensitivity of soil carbon decomposition and feedbacks to climate change. Nature 440:165-73.

De Deyn GB, Cornelissen JHC, Bardgett RD. 2008. Plant functional traits and soil carbon sequestration in contrasting biomes. Ecol Lett 11:516-31.

Díaz S, Lavorel S, de Bello F, Quétier F, Grigulis K, Robson TM. 2007. Incorporating plant functional diversity effects in ecosystem service assessments. Proc Natl Acad Sci 104:20684-9.
Dijkstra FA, Prior SA, Runion GB, Torbert HA, Tian H, Lu C, Venterea RT. 2012. Effects of elevated carbon dioxide and increased temperature on methane and nitrous oxide fluxes: evidence from field experiments. Front Ecol 10:520-7.

Dorrepaal E, Toet S, van Logtestijn RSP, Swart E, van de Weg MJ, Callaghan TV, Aerts R. 2009. Carbon respiration from subsurface peat accelerated by climate warming in the subarctic. Nature 460:616-19.

Ellis T, Hill PW, Fenner N, Williams GG, Godbold D, Freeman C. 2009. The interactive effects of elevated carbon dioxide and water table draw-down on carbon cycling in a Welsh ombrotrophic bog. Ecol Eng 35:978-86.

Freeman C, Evans CD, Monteith DT, Reynolds B, Fenner N. 2001. Export of organic carbon from peat soils. Nature 412:785.

Freeman C, Lock MA, Reynolds B. 1992. Fluxes of $\mathrm{CO}_{2}, \mathrm{CH}_{4}$ and $\mathrm{N}_{2} \mathrm{O}$ from a Welsh peatland following simulation of water table draw-down: potential feedback to climatic change. Biogeochemistry 19:51-60.

Grayson R, Holden J. 2012. Continuous measurement of spectrophotometric absorbance in peatland stream water in northern England: implications for understanding fluvial carbon fluxes. Hydrol Process 26:27-39.

Holden J. 2005. Peatland hydrology and carbon cycling: why small-scale process matters. Philos Trans R Soc A 363:2891-913.

Ise T, Dunn AL, Wofsy SC, Moorcroft PR. 2008. High sensitivity of peat decomposition to climate change through watertable feedback. Nat Geosci 1:763-6.

Jenkins GJ, Perry MC, Prior MJ. 2008. The climate of the United Kingdom and recent trends. Exeter, UK: Met Office Hadley Centre.

Jobbágy EG, Jackson RB. 2000. The vertical distribution of soil organic carbon and its relation to climate and vegetation. Ecol Appl 10:423-36.

Kellner E, Waddington JM, Price JS. 2005. Dynamics of biogenic gas bubbles in peat: potential effects on water storage and peat deformation. Water Resour Res 41:W08417.

Kettridge N, Baird A. 2008. Modelling soil temperatures in northern peatlands. Eur J Soil Sci 59:327-38.

Kutsch WL, Bahn M, Heinemeyer A. 2009. Soil carbon relations: an overview. In: Kutsch WL, Bahn M, Heinemeyer A, Eds. Soil carbon dynamics: an integrated methodology. Cambridge: Cambridge University Press. p 1-15.

Lavorel S, Díaz S, Cornelissen JH, Garnier E, Harrison S, McIntyre S, Pausas J, Pérez-Harguindeguy N, Roumet C, Urcelay C. 2007. Plant functional types: are we getting any closer to the Holy Grail? In: Canadell J, Pataki D, Pitelka L, Eds. Terrestrial ecosystems in a changing world. Berlin: Springer. p 149-64.

Levy PE, Burden A, Cooper MDA, Dinsmore KJ, Drewer J, Evans C, Fowler D, Gaiawyn J, Gray A, Jones SK, Jones T, McNamara NP, Mills R, Ostle N, Sheppard LJ, Skiba U, Sowerby A, Ward SE, Zieliński P. 2012. Methane emissions from soils: synthesis and analysis of a large UK data set. Glob Change Biol 18:1657-69.

Marschall M, Proctor MCF. 2004. Are bryophytes shade plants? Photosynthetic light responses and proportions of chlorophyll a, chlorophyll b and total carotenoids. Ann Bot 94:593-603.

Moore T, Bubier J, Bledzki L. 2007. Litter decomposition in temperate peatland ecosystems: the effect of substrate and site. Ecosystems 10:949-63.

Moore T, Young A, Bubier J, Humphreys E, Lafleur P, Roulet N. 2011. A multi-year record of methane flux at the Mer Bleue Bog, Southern Canada. Ecosystems 14:646-57. 
Rodwell JS. 2000. British plant communities. MARITIME communities and vegetation of open habitats, Vol. 5Cambridge: Cambridge University Press.

Schielzeth H. 2010. Simple means to improve the interpretability of regression coefficients. Methods Ecol Evol 1:103-13.

Schmidt SK, Costello EK, Nemergut DR, Cleveland CC, Reed SC, Weintraub MN, Meyer AF, Martin AM. 2007. Biogeochemical consequences of rapid microbial turnover and seasonal succession in soil. Ecology 88:1379-85.

StataCorp. 2013. Stata statistical software: release 13. Texas: Stata Press.

Strack M, Waddington JM, Bourbonniere RA, Buckton EL, Shaw K, Whittington P, Price JS. 2008. Effect of water table drawdown on peatland dissolved organic carbon export and dynamics. Hydrol Process 22:3373-85.

Ström L, Tagesson T, Mastepanov M, Christensen TR. 2012. Presence of Eriophorum scheuchzeri enhances substrate availability and methane emission in an Arctic wetland. Soil Biol Biochem 45:61-70

Sturm M, Racine C, Tape K. 2001. Climate change: increasing shrub abundance in the Arctic. Nature 411:546-7.

Toet S, Cornelissen JC, Aerts R, Logtestijn RP, Beus M, Stoevelaar R. 2006. Moss responses to elevated $\mathrm{CO}_{2}$ and variation in hydrology in a temperate lowland peatland. Plant Ecol 182:27-40.

Turetsky MR. 2003. The role of bryophytes in carbon and nitrogen cycling. The Bryologist 106:395-409.
Turetsky MR, Crow SE, Evans RJ, Vitt DH, Wieder RK. 2008. Trade-offs in resource allocation among moss species control decomposition in boreal peatlands. J Ecol 96:1297-305.

van Winden JF, Reichart G-J, McNamara NP, Benthien A, Damsté JSS. 2012. Temperature-induced increase in methane release from peat bogs: a mesocosm experiment. PLoS One 7:e39614.

Waddington JM, Roulet NT. 2000. Carbon balance of a boreal patterned peatland. Glob Change Biol 6:87-97.

Ward S, Bardgett R, McNamara N, Adamson J, Ostle N. 2007. Long-term consequences of grazing and burning on northern peatland carbon dynamics. Ecosystems 10:1069-83.

Ward SE, Bardgett RD, McNamara NP, Ostle NJ. 2009. Plant functional group identity influences short-term peatland ecosystem carbon flux: evidence from a plant removal experiment. Funct Ecol 23:454-62.

Ward SE, Ostle NJ, Oakley S, Quirk H, Henrys PA, Bardgett RD. 2013. Warming effects on greenhouse gas fluxes in peatlands are modulated by vegetation composition. Ecol Lett 16:1285-93.

Weedon JT, Kowalchuk GA, Aerts R, van Hal J, van Logtestijn R, Tas N, Röling WFM, van Bodegom PM. 2012. Summer warming accelerates sub-arctic peatland nitrogen cycling without changing enzyme pools or microbial community structure. Glob Change Biol 18:138-50.

Yu Z, Loisel J, Brosseau DP, Beilman DW, Hunt SJ. 2010. Global peatland dynamics since the last glacial maximum. Geophys Res Lett 37:L13402. 